Trinity University

Digital Commons @ Trinity

2015

\title{
Are Self-Made Men Made Equally? An Experimental Test of Impartial Redistribution and Perceptions of Self-Determination
}

\author{
David Chavanne \\ Kevin McCabe \\ Maria Pia Paganelli \\ Trinity University, mpaganel@trinity.edu
}

Follow this and additional works at: https://digitalcommons.trinity.edu/econ_faculty

Part of the Economics Commons

\section{Repository Citation}

Chavanne, D., McCabe, K., \& Paganelli, M. P. (2015). Are self-made men made equally? An experimental test of impartial redistribution and perceptions of self-determination. Nordic Journal of Political Economy, 40, Article 3. http://doi.org/10.2139/ssrn.1534934

This Post-Print is brought to you for free and open access by the Economics Department at Digital Commons @ Trinity. It has been accepted for inclusion in Economics Faculty Research by an authorized administrator of Digital Commons@ Trinity. For more information, please contact jcostanz@trinity.edu. 


\title{
Are Self-Made Men Made Equally? An Experimental Test of Impartial \\ Redistribution and Perceptions of Self-Determination
}

\author{
David Chavanne \\ Kevin McCabe \\ Maria Pia Paganelli
}

June 11, 2014

\begin{abstract}
Using a laboratory experiment, we examine if third party redistribution from a "Have" to a "Have-not" is affected by (1) whether a Have's advantage is in some way self-determined and (2) whether selfdetermination occurs in two dimensions compared to one dimension. We find that redistribution decreases if a Have earns an advantageous opportunity or earns income. But we also find that redistribution does not decrease any further if a Have earns both an opportunity and income.

These results suggest that, in line with existing work, the perception that advantages are self-determined matters for redistribution. But the results also suggest that, once one develops the perception that self-determination exists, additional dimensions self-determination may not matter on the margin. We also find that stakeholders' expectations of redistribution do not depend on whether advantages in the experiment are self-determined. Expectations instead depend on whether a stakeholder is a Have or a Have-not.
\end{abstract}

Keywords: redistribution, deservingness, experiments, luck 
Debates over income inequality, CEO compensation, welfare policies and other issues involving political redistribution demonstrate that people care, often passionately, about how resources get distributed in society. Much survey and experimental research demonstrates that beliefs regarding the roles of effort and luck - whether advantages are self- or exogenously-determined (Fong, 2001) - drive choices and preferences that involve the distribution (or redistribution) of money. Less attention has been paid, however, to addressing how perceptions of self-determination relate to actual selfdetermination. Given established connections between (1) beliefs about selfdetermination and preferences for political redistribution (Alesina and La Ferrera, 2005; Boarini and Le Clainche, 2009; Corneo and Gruner, 2002; Fong, 2001; Gaeta, 2011) and (2) beliefs about self-determination and actual redistributive policies (Alesina et al, 2001; Blank, 2003; Larsen, 2008) these questions are not trivial; a deeper understanding of the relation between perceptions of self-determination and actual self-determination represents an important link in the causal chain that connects these perceptions to preferences and, ultimately, redistributive policies. A better understanding of how people assess self-determination will shed light on redistributive policies, as well as point to the degree to which such assessments might be malleable.

Perceptions of self-determination have been shown to affect income distribution in experimental tasks, contextualized hypothetical surveys, and large-scale surveys that elicit citizens' policy preferences. Across these various types of studies, a robust finding emerges in both experiments and surveys: advantages that are attributed to effort are rewarded, while advantages that are attributed to luck are not. These results provide empirical support for liberal egalitarian theories of distributive justice, which claim that 
unequal outcomes should be permitted to the extent they stem from choices rather than uncontrollable factors (Cappelen and Tungodden, 2006). Both theory and empirical findings, therefore, point to moral intuitions that hold people responsible for outcomes that stem from choices, and thereby permit asymmetries in economic advantages that are perceived as being self-determined.

Given the empirical and theoretical connection between self-determination, attitudes toward deservingness, and income distribution, we examine whether or not perceptions of self-determination come from a fine-tuned, multi-dimensional assessment of situational factors in a controlled laboratory task in which people make impartial redistributive choices with real money. The experiment varies the degree to which economic advantages are self-determined across four treatments. In one treatment, a stakeholder earns the opportunity to acquire future income. In a second treatment, a stakeholder earns the income itself. In a third treatment, a stakeholder earns both the opportunity and the income. In a fourth treatment a stakeholder earns neither the opportunity nor the income. Across all four treatments, an impartial third party is given the option to redistribute any portion of the advantaged stakeholder's income to another stakeholder who did not have the opportunity to earn money. The treatment variables (opportunity and income) are intended to represent two aspects of one's life history that may or may not be perceived as being self-determined. People have perceptions regarding whether opportunities and income are self-determined (e.g. from self-made personal development, one's own hard work) or exogenously-determined (e.g. from nepotism, having a privileged upbringing, acquiring wealth without working hard). 
The design therefore tests if redistributive behavior in a simple three-player dictator game is affected by (1) whether advantages are self-determined and (2) whether self-determination occurs in two dimensions compared to one dimension. We find that, consistent with previous studies, redistribution by a third-party decision maker decreases with self-determination. But we also find that redistribution does not decrease any further when the endowed stakeholder earns both his opportunity and his income. Additionally, we find that stakeholders base their expectations of redistribution on whether they are the Have or the Have-not, and not on the earning conditions in their particular treatment. With the Haves expecting less redistribution than the Have-nots in all treatments, the impartial decision makers redistribute in a way that is consistent with the expectations of the Haves whenever there is something earned (the opportunity and/or the income); whenever there is nothing earned, the impartial decision makers redistribute in a way that is consistent with the expectations of the Have-not.

The paper is organized as follows. The next section embeds our work within the socio economics literature on income redistribution and specifically describes research that addresses connections between self-determination and income distribution. Subsequent sections describe our experiment's hypotheses, design, and results. A discussion section offers interpretations and implications of the results.

\section{Preferences for Redistribution and Empirical Work}

As highlighted by Alesina and Giuliano (2010), the socio-economics literature identifies three, non-mutually-exclusive sources of explanations for why people care about the 
distribution of income. First, income redistribution may affect someone's actual or expected income, either through preferences for immediate transfers given one's current economic standing (Alesina and Giuliano, 2010; Fong, 2001; Luttmer, 2001; Meltzer and Richard, 1981) or expectations of future transfers given one's expected future income (Benabou and Ok, 2001; Piketty, 1995). Second, people may care about the distribution of income because of externalities associated with the distribution that affect their wellbeing; these may include societal education levels (Benabou, 1996; Galor and Zeira, 1993; Perotti, 1993), crime rates (Piven and Cloward, 1971) and/or incentives to work (Moffitt, 1992; Piketty, 1995). Third, the distribution of income may, in itself, be a direct component in people's utility functions. Preferences over particular distributions of income may stem from concerns for others (Gilens, 1999), beliefs about the causes of inequality (Alesina and La Ferrera, 2005; Alesina and Angeletos, 2005; Boarini and Le Clainche, 2009; Corneo and Gruner, 2002; Fong, 2001; Gaeta, 2011), and/or feelings of group loyalty (Luttmer, 2001).

The experiment presented in this paper extends work that examines direct preferences over the distribution of income. Specifically, the experiment's design is motivated by a great deal of empirical work (described below) that links beliefs about the role of self-determination in the economy and attitudes toward the distribution of income. This connection has been established in research that spans different methods, including lab experiments, vignette-based contextual surveys and macro-level surveys. Since the connection between beliefs about self-determination and income distribution is so robust, we seek to provide a better understanding of how beliefs about the role of selfdetermination are formed. 
Laboratory experiments are well-suited to address how people react to differences in the degree of self-determination because such differences can be easily and clearly induced. While the initial waves of economics experiments assigned roles and income randomly, researchers later became interested in whether outcomes changed when advantages were earned through performance on tasks such as strategy games, quizzes, or manual labor. Hoffman and Spitzer (1985), in a two-person bargaining experiment, found that proposers who earned their advantageous position by winning a strategy game allocated more money to themselves compared to proposers who did not earn their position. Burrows and Loomes (1994) found that a bargainer is more likely to protect a favorable endowment differential if the larger endowment was the result of effort. Hoffman et al (1994) extended the result to ultimatum ${ }^{1}$ and dictator games ${ }^{2}$, while Cherry et al (2002) and Oxoby and Spraggon (2008) showed that, in dictator games, decision makers who earn their distributive stakes keep more of it compared to decision makers whose stakes are arbitrarily assigned by experimenter. Ruffle (1998) found that recipients (rather than decision makers) in dictator games who earned the distributive stakes through superior performance on a quiz were rewarded relative to those whose stakes were determined by an experimenter. Fong and Oberholzer-Gee (2011) used the dictator game to show that people withhold cash transfers from poor people who are perceived as not being deserving. In a series of papers by Cappelen, Tungodden and co-authors (Cappelen et al, 2007; Cappelen et al, 2010; Cappelen et al, 2013) a production stage preceded a redistribution stage in a dictator game, which allowed the redistributable

\footnotetext{
${ }^{1}$ In ultimatum games (Guth et al, 1982), one person who has money makes an offer to a paired receiver who does not have money. The receiver can either accept the offer or reject it. If the offer is rejected, both players receive 0 .

${ }^{2}$ The dictator game (Forsythe et al, 1994) is identical to the ultimatum game except that the receiver in the dictator game does not have the option to reject the offer.
} 
stakes to be decomposed into income generated by controllable and uncontrollable factors; dictators in these games, therefore, know the extent to which each person's contribution to the redistributable pool was self-determined or exogenous. Cappelen et al (2007), found pluralism in fairness ideals, with 38.1 percent of subjects being classified as liberal egalitarians. Cappelen et al (2010) reached similar conclusions, but also found that the likelihood of holding others responsible for exogenous factors increases with work experience. Cappelen et al (2013) found that people are more likely to reduce inequalities that stem from differences in luck compared to inequalities that stem from differences in choices.

Other experiments have extended the above findings to three-person games in which decision makers, without any of their own money at stake, must allocate a fixed pie of income across two others. With monetary incentives removed, decisions reveal normative standards of fairness. Dickinson and Tiefenthaler (2002) showed that third parties reward stakeholders who earn an advantageous position, while third parties do not reward stakeholders who acquire an advantageous position due to luck. Konow (2000) showed that third parties reward stakeholders who contributed more to a distributive pool by doing more work; third parties did not reward stakeholders who made greater contributions to the pool because they were lucky to be randomly assigned a higher value for a given unit of output.

Outside of the laboratory, contextualized surveys, describing hypothetical vignettes, have examined distributive choices of impartial observers. Respondents must allocate a surplus across fictional stakeholders who differ in needs, tastes, beliefs, effort and/or ability. Faravelli (2007), Konow (1996, 2001, 2009), Schokkaert and Capeau 
(1991) and Schokkaert and Overlaet (1989) all found that third parties reward stakeholders according to their effort, but not according to luck. Moreover, results reveal substantial support for what Konow $(1996,2000,2001)$ calls the accountability principle - output (e.g. goods or money) is distributed in proportion to inputs that come from effort, while differences in uncontrollable inputs (e.g. luck, innate ability) are ignored. The accountability principle represents an extension of equity theory (Adams, 1965; Homans, 1958), which predicts that people who contribute to a social surplus are rewarded in proportion to their relative contribution.

A second type of survey research establishes a connection between perceptions of self-determination and income distribution by eliciting both preferences for political redistribution and beliefs about the roles of luck and effort in society. Using Gallup Poll data, Fong (2001) found that preferences for redistributive policies are significantly affected by whether one thinks that luck or effort plays a larger role in determining life outcomes. Alesina and La Ferrera (2005) reached a similar conclusion for U.S. citizens using GSS data. Corneo and Gruner (2002) extended the finding to international data, while Boarini and Le Clainche (2009) showed the same result with French data and Gaeta (2011) did likewise for Italian data. Kangas (2003) identified a "deservingness bonus"defined as the percentage difference between a society's preferred benefits for the undeserving poor and their preferred benefits for the deserving poor - in the Finnish population. Fong et al (2004) explained this relationship between beliefs about luck/effort and redistribution in terms of the human tendency for strong reciprocity, while Benabou and Tirole (2006) used the relationship to justify their claim that people have a tendency to believe in a just world. 
Across these different methods, an underlying theme emerges: when there is a perception that one's income is self-determined, either (1) he chooses to keep more of it, (2) others choose that he keeps more of it, or (3) others declare preferences for policies that allow him to keep more of it. Equity theory and the accountability principle make clear predictions that effort will be proportionally rewarded when the proportions are known (e.g. when decision makers or respondents know that one person worked X times as hard as the other person). When proportions are not known - like in experiments in which superior performers on a preliminary task acquire advantages, or on surveys that ask for a general opinion regarding whether success and failure depends on hard work the effect is a shift in preferences that skews distribution toward someone who earns his relative success or toward someone who is relatively unfortunate through no fault of his own.

This earlier work leads to the general implication that a greater perceived role of self-determination leads to a greater acceptance of income disparity. It leaves unanswered, however, the question as to how people perceive self-determination given the complex ways in which luck and effort interact. If Person $\mathrm{C}$ is told that that Person $\mathrm{A}$ works harder than Person B, then Person C will likely tolerate Person A having a larger income. But what if the Person $\mathrm{C}$ is also told that Person $\mathrm{A}$ was fortunate to have his parents pay for his college education, while Person B could not afford college? How does the introduction of a second dimension that is relevant to self-determination affect the preferred income distribution?

Our design is intended to answer the core question that emerges from considering this scenario: Are perceptions of self-determination fine-tuned along the dimensions of 
opportunity and income accumulation? If so, this would imply that policy preferences are sensitive to messages regarding how self-determination contributes to the various inputs to economic success. Or, alternatively, do people form perceptions of self-determination without considering the multiple dimensions that contribute to it? If so, one should expect policy preferences to be less sensitive to messages regarding the role of selfdetermination.

\section{Design}

Following the taxonomy described by Smith (1982), we vary environmental properties associated with how roles are determined and how income is acquired within an experimental institution defined by anonymity and impartial third-party decisions. Specific treatment procedures are summarized in Table 1. Across all of the experiment's treatments, a decision maker was paired with a sender and a receiver. ${ }^{3}$ The sender acquired money and the decision maker was given the opportunity to send any portion of the sender's money to the receiver. Differences between treatments stem from how senders' and receivers' roles were assigned (earned or given roles) and how senders' initial endowments were acquired (earned or given income).

[Insert Table 1 about here.]

\footnotetext{
${ }^{3}$ Subjects were referred to as decision makers, senders and receivers throughout the experiment. While we cannot rule out the possibility that the labels influenced behavior in some absolute sense, potential reactions to the terminology cannot explain differences across treatments.
} 
Across our treatments, we followed procedures that have been used in several of the experiments cited in the previous section to induce different conditions of earning. Roles were assigned either randomly or by performance on a quiz. In earned-role treatments, all non-decision makers took a current-events quiz. ${ }^{4}$ All subjects were told that those who ranked in the top half of the distribution of scores would be senders and those who ranked in the bottom half of the distribution would be receivers. In given-role treatments, all roles were determined by the random selection of identification letters prior to the experiment.

In earned-income treatments, senders were given seven minutes to work on a challenging word-search task, earning $\$ 2$ for each word that they found. ${ }^{5}$ In givenincome treatments, senders received the amount of money written on a randomly drawn ticket. The distribution of amounts in treatments with tickets mimicked a distribution from a treatment with earned income.

With both roles and income being associated with either a given or earned process, the experiment includes the following four treatments, illustrated in Table 2: givenR-givenI, givenR-earnedI, earnedR-givenI and earnedR-earnedI, where *R $(* \mathrm{I})$ denotes the type of process that determines roles (income).

[Insert Table 2 about here.]

\footnotetext{
${ }^{4}$ Hoffman et al. (1994) used a current events quiz to assign roles; Ruffle (1998) used "general knowledge and skill-testing questions" (p. 251) to assign levels of wealth, while Cherry et al. (2002) used questions from the Graduate Management Admission Test (GMAT) and Oxoby and Spraggon (2008) used a combination of GMAT and Graduate Record Examination (GRE) questions.

${ }^{5}$ Senders' earnings from the word search ranged from $\$ 4$ to $\$ 36$. Median earnings from the word search were $\$ 17$.
} 


\section{Events and Procedures}

Since we are interested in whether redistribution is influenced by the historical process that led up to the Haves getting in their fortunate position, the design holds all procedures constant across treatments except for the ways in which roles and income are acquired. We recruited 336 subjects via an online database made up of undergraduate and graduate students at George Mason University. We ran 24 sessions with fourteen subjects each. All subjects signed a consent form, received a show-up fee ${ }^{6}$ and drew a slip of paper from a container.

In given-role treatments, the main instructions immediately followed the drawing of slips. The instructions explained the procedures and told subjects that those who drew A-D would be senders, those who drew E-H would be decision makers, and those who drew I, J, K or N would be receivers; the two people who drew Ms would be monitors. After the instructions were read both silently and aloud, all senders and receivers were brought by experimenters to different rooms. Decision makers remained in the lab.

In earned-role treatments, subjects drew eight slips labeled "Q," four labeled "D," and two labeled "M." A preliminary set of instructions then told all participants that the eight people with "Qs" would take a quiz, and "the four Qs who score highest will earn an opportunity to make money." The four people who drew Ds (decision makers) and the two people who drew Ms (monitors) were told to wait silently while the others took the quiz. After the quiz, the main instructions were read both silently and aloud. The experimenters sorted the eight subjects who took the quiz into senders and receivers

\footnotetext{
${ }^{6}$ Show up fees were either of $\$ 7.00$ or $\$ 7.50$. Lab procedures changed in the midst of data collection. The change in show-up fees reflects the required alignment of show-up fees with another laboratory on campus. A regression analysis shows that no substantive differences in behavior can be attributed to the change in the show-up fee.
} 
based on performance and brought the two groups to different rooms. Decision makers remained in the lab.

Across all treatments, we used monitors to create double-blind procedures similar to Hoffman et al. (1996). We coded all materials used throughout the experiment with an identification letter, and monitors silently passed them out and collected them. In this way the monitors knew the mapping from subject to ID, the experimenters knew the mapping from ID to decisions, while nobody knew the mapping from subjects to decisions. All subjects were also told that the monitors were responsible for ensuring that experimenters followed the instructions.

The procedure for the senders was the following. In given-income treatments, each sender drew a slip of paper with an amount of money written on it. The written amount determined their endowment. In earned-income treatments, each sender worked on the word search. In all treatments, senders received an envelope that contained the money that they either earned or were given. The monitor then collected all of the envelopes with the endowments and brought them to the decision makers. Senders took a questionnaire that tested for comprehension of the instructions. The following question elicited expectations ${ }^{7}$, conditional on the amount of money that they either earned or were given:

You earned/have been given $\$ \underline{X}$.

How much do you expect your paired Decision Maker to have you send to your paired Receiver? \$

\footnotetext{
${ }^{7}$ Since subjects were not rewarded for accurate expectations, we cannot rule out the possibility that incentives for accuracy would have affected expectations.
} 
The procedure for the decision makers was the following. First, we gave decision makers a questionnaire to test comprehension. ${ }^{8}$ Then we compensated them for their time and decisions by letting them earn money with the same word search that determined the senders' stakes. ${ }^{9}$ We then gave them a decision form stating the amount endowed to a sender. Decision makers decided how much of the endowment should be redistributed to the unendowed stakeholder, and gave the envelope with the decision form to a monitor who brought them all to the receivers' room. At this point decision makers were paid and dismissed.

The procedure for receivers was as follows. While receivers waited for the decision makers' decisions, they filled out questionnaires that tested their comprehension of the instructions and elicited expectations (conditional on the senders' stakes) with the following question:

Your paired Sender earned/has been given $\$ \underline{X}$. How much do you expect your paired Decision Maker to have the Sender send to you? \$

\footnotetext{
${ }^{8}$ The first section of the questionnaire listed the number of questions that eight hypothetical subjects answered correctly on the quiz. Respondents were required to denote which scores belong to senders and which scores belong to receivers. The second section tested for understanding of the decision process. In a table, amounts of words found (in treatments in which senders earn their money) or amounts written on tickets (in treatments in which senders are given their money) were listed. Subjects were required to state the amounts of money associated with each performance on the word search or each of the selected tickets. The table also listed a series of decision makers' hypothetical decisions. Subjects were required to specify the earnings that each decision would generate for each sender and receiver. All decision makers were given two questionnaires sequentially. After the first questionnaire, an experimenter corrected any mistakes. A monitor then returned the original questionnaire and passed out a second one. If mistakes were made on this second questionnaire, the subject's decision was excluded from the analysis. All references made to "correct" or "incorrect" questionnaires refer to this second-chance questionnaire. ${ }^{9}$ Decision Makers needed to be compensated for their time, and we chose to pay them based on performance on the word search. This choice models a situation where people making redistributive decisions share an experience with the Haves. Additional treatments, which are described in a separate working paper, show that decision makers who earned money (with the word search) did not behave differently compared to decision makers who were given money (through randomization).
} 
After decision makers made their decisions, all decision forms and money were brought to the receivers' room, where an experimenter put the proper amount in each subject's envelope. Receivers and senders were then dismissed separately.

Decision forms provided the following information in given-income treatments:

Sender $\mathrm{X}$ was given $\$ \underline{X}$.

The receiver with whom $\mathrm{s} /$ he is randomly paired was given $\$ 0$. I choose to have sender $\mathrm{X}$ send $\$$ __ to the receiver with whom $\mathrm{s} /$ he is randomly paired.

In earned-income treatments, "Sender $\mathrm{X}$ has earned $\$ \underline{X}$ " replaced the first line from above.

\section{Hypotheses}

Our design allows us to test how variation in the earning conditions affect the percentage redistributed to the disadvantaged stakeholder.

When neither the senders' roles nor incomes were earned, we expected the sender's preexisting entitlement to be perceived as being exogenously-determined, by luck, which should result in redistribution of roughly half of the senders' income. Letting $\alpha_{\text {givenR-givenI }}$ denote the median percentage redistributed in the treatment with given roles and given income, the hypothesis can be formally stated as follows:

- $\mathrm{H}_{\mathrm{a} 0}: \alpha_{\text {givenR-givenI }}=1 / 2$

- $\mathrm{H}_{\mathrm{a} 1}: \alpha_{\text {givenR-givenI }} \neq 1 / 2$

We predicted that when either incomes or roles are earned, there would be a lower level of redistribution compared to when neither was earned, as previously demonstrated 
in the literature. Letting $\mathrm{F}(\alpha * *)$ denote the distribution of percentages redistributed in the specified treatment, these hypotheses can be stated as follows:

- Roles $\mathrm{H}_{0}: \mathrm{F}\left(\alpha_{\text {givenR-givenI }}\right)=\mathrm{F}\left(\alpha_{\text {earnedR-givenI }}\right)$

- Roles $\mathrm{H}_{1}: \mathrm{F}\left(\alpha_{\text {givenR-givenI }}\right)>\mathrm{F}\left(\alpha_{\text {earnedR-givenI }}\right)$

- Income $\mathrm{H}_{0}: \mathrm{F}\left(\alpha_{\text {givenR-givenI }}\right)=\mathrm{F}\left(\alpha_{\text {givenR-earnedi }}\right)$

- Income $\mathrm{H}_{1}: \mathrm{F}\left(\alpha_{\text {givenR-given }}\right)>\mathrm{F}\left(\alpha_{\text {givenR-earnedi }}\right)$

The most important question that emerges from the design involves asking how redistribution when both income and roles were earned compared to redistribution when only one was earned. When both roles and income were earned, we expected lower levels of redistribution than when only one was earned. This hypothesis can be stated as follows:

- Joint $\mathrm{H}_{0 \mathrm{a}}: \mathrm{F}\left(\alpha_{\text {givenR-earnedI }}\right)=\mathrm{F}\left(\alpha_{\text {earnedR-earnedI }}\right)$

- Joint $\mathrm{H}_{1 \mathrm{a}}: \mathrm{F}\left(\alpha_{\text {givenR-earnedI }}\right)>\mathrm{F}\left(\alpha_{\text {earnedR-earnedI }}\right)$

And:

- Joint $\mathrm{H}_{0 b}: \mathrm{F}\left(\alpha_{\text {earnedR-givent }}\right)=\mathrm{F}\left(\alpha_{\text {earnedR-earnedI }}\right)$

- Joint $\mathrm{H}_{1 \mathrm{~b}}: \mathrm{F}\left(\alpha_{\text {earnedR-givent }}\right)>\mathrm{F}\left(\alpha_{\text {earnedR-earnedI }}\right)$

Rejection of these two hypotheses suggests that decision makers' preference for redistribution came from an assessment of how both roles and income were determined. Failure to reject the two joint hypotheses, combined with rejection of the separate Roles and Income hypotheses, suggests that decision makers' preference for redistribution came from a binary assessment of whether any factor was self-determined.

We can also specify hypotheses that compare (1) sender expectations with receiver expectations and (2) impartial decisions with sender and/or receiver expectations. Given the lack of previous research addressing expectations and impartial 
decision making, we did not have preconceived predictions regarding whether the data would support these various hypotheses.

\section{Results}

24 decisions were collected in each of the four treatments, for a total of 96 decisions. Table 3 shows descriptive statistics, both across entire treatments and conditional on the amounts available for redistribution. The statistics sorted by senders' stakes shows no systematic relationship between the size of the redistributable pie and the amount of redistribution.

[Insert Table 3 about here.]

Figure 1 displays the cumulative distribution functions of percentages sent, while Table 4 presents the results of pairwise Wilcoxon rank-sum tests. The three main results from the experiment will be presented in turn. Additional results regarding expectations will follow.

[Insert Figure 1 about here.]

[Insert Table 4 about here.]

Result 1: Redistribution was highest in the givenR-givenI treatment. 
A sign test confirms that the median percentage sent in this treatment is not statistically different from $1 / 2(p=0.22) .18$ out of the 24 third-party decision makers in the givenR-givenI treatment redistributed half of the sender's income.

Result 2: The existence of earned income or earned roles decreased redistribution.

The median percentage sent in the givenR-earnedI (earnedR-givenI) treatment is $0.354(0.405)$. Visually, the effect of earned roles can be seen by comparing the cumulative distribution functions of the givenR-givenI and earnedR-givenI treatments, which are each marked with triangles in Figure 1. A rank-sum statistic of $2.90(p=.004)$ allows rejection of the hypothesis that earned roles had no effect. Likewise, the effect of earned income can be seen by comparing the givenR-givenI and givenR-earnedI distributions - both emboldened in Figure 1. A rank-sum statistic of $3.46(\mathrm{p}=.0005)$ allows rejection of the hypothesis that earned income had no effect.

Result 3: Despite these two separate effects, redistribution did not decrease further when both earning conditions were met.

The median percentage sent in the earnedR-earnedI treatment was 0.345 . The distribution of percentages sent in the earnedR-earnedI treatment is shown by the lightlyshaded line marked with squares in Figure 1. Rank-sum tests show that redistribution in the earnedR-earnedI treatment is not significantly lower than redistribution in the treatment with only earned income $(\mathrm{z}=0.00, \mathrm{p}=1.00)$ or the treatment with only earned 
roles $(\mathrm{z}=1.139, \mathrm{p}=.255)$. Although the existence of earned roles and earned income each separately decreased redistribution, the simultaneous existence of both did not lead to any further decrease.

Regarding expectations, Table 5 presents descriptive statistics, sorted by treatment and the source of expectations (senders or receivers). ${ }^{10}$ Figure 2 shows the cumulative distribution functions for sender expectations, receiver expectations and actual decisions within each treatment. Table 6 shows the results of rank-sum tests that compare senders' and receivers' expectations.

[Insert Table 5 about here.]

[Insert Figure 2 about here.]

[Insert Table 6 about here.]

Result 4: Stakeholders with possession expected less redistribution than stakeholders without possession; expectations did not depend on earning conditions.

Within all treatments, senders expected less redistribution than receivers; the difference is significant in the three earning treatments and approaches significance in the no earning treatment. Neither expectations of senders nor receivers varied significantly across treatments: neither senders nor receivers anticipated the extent to which earning would influence decision makers. Figure 2 and the last column in Table 5 show that actual decisions met senders' expectations in treatments in which there is at least one earned

\footnotetext{
${ }^{10}$ Expectations from senders and receivers who answered the questionnaire incorrectly or submitted invalid responses were dropped from the analysis. Results do not substantively change when expectations from erroneous questionnaires are included.
} 
component (and decisions were significantly different from receivers' expectations) and that actual decisions met receivers' expectations in the treatment in which there is no earned component (and decisions were significantly different from senders' expectations).

\section{Discussion}

While the logic of earlier work suggests that a greater number of self-determined processes along the path to acquiring economic advantages should lead to greater acceptance of income disparity, our results suggest otherwise. The decisions of impartial third-party redistributors in the experiment are driven by whether or not advantages are self-determined in some manner, but not by whether self-determination characterizes multiple components throughout the process. In line with Kangas (2003), we find a "deservingness bonus" granted to the Haves in our experiment: deserving Haves are allowed to keep more than undeserving Haves. Our result extends this framework, however, by pointing to the absence of what could be thought of as an "extradeservingness" bonus: Haves who earn their advantage in two ways are not allowed to keep more than Haves who earn their advantage in only one way.

Previous work has shown that, when a redistributable pie is decomposed into controllable parts and uncontrollable parts, people are more likely to permit inequality that stems from the controllable parts (Cappelen et al, 2007; Cappelen et al, 2010; Cappelen et al, 2013). Our experiment shifts the focus away from studying redistribution when controllable and uncontrollable factors are decomposed into known quantities; 
instead, we study redistribution in cases where the redistributor has no insight into the precise degrees to which luck and effort contribute to economic advantage. Such was the case across other experiments in which performance on strategy games, quizzes or cognitive exercises (tasks where success depends on some mixture of talent and effort) generated either earned opportunities (Burrows and Loomes, 1994; Dickinson and Tiefenthaler, 2004; Hoffman and Spitzer, 1985; Hoffman et al, 1994) or earned income (Cherry et al, 2002; Konow, 2000; Oxoby and Spraggon 2008). These experiments, too, show empirical support for liberal egalitarian principles of distributive justice, as the presence of earned opportunity or earned income each leads to more unequal outcomes. Our design tests whether the simultaneous existence of earned opportunity and earned income exerts an additive effect on redistribution. Since our results show that it does not, they point to a redistributive choice where greater degrees of self-determination (two dimensions of earning instead of one) do not lead to a greater tolerance for inequality.

The behavior that we observe likely stems from a cognitive strategy that involves reliance on a heuristic. Given that their choices are payoff-neutral, and given the complex nature of the situation in which they are placed, Decision Makers in our experiment may simply be looking to see if Senders did anything to deserve a greater share than the Receivers - and then redistributing less (more) if the answer is yes (no). ${ }^{11}$ This type of cognitive process would be consistent with theories of how voters form preferences for political redistribution given social complexity. Someone making a generalized judgment about whether people in society deserve their advantages will rely on ideology or other cognitive heuristics to circumvent this complexity and reach a conclusion (Petersen et al, 2011).

${ }^{11}$ We thank an anonymous referee for making this point. 
Thus, our Decision Makers and voters both seem to cope with a complex social environment, where luck and effort interact in complicated ways, by searching for a sign that self-determination exists rather than by carefully reflecting on the scope of selfdetermination. Our results make a novel contribution by providing evidence that reliance on this heuristic is induced in a relatively simple environment, with only two stakeholders and only two dimensions that are relevant to assessments of self-determination.

With inequality and political redistribution being popular topics within policy debates, a better understanding of how people assess self-determination can shed light on voter preferences, political rhetoric and the ultimate policies that emerge. The experimental results presented here suggest that people form perceptions of relative deservingness - which in turn shape redistributive preferences - through a binary assessment of whether self-determination exists. We find a similar binary mode of assessment in the expectations of the stakeholders, although it is based on one's possession - or lack of possession - rather than on conditions of self-determination: Haves expected similar distributions of redistributive decisions regardless of how they came to possess their stakes; likewise, Have-nots expected a similar distribution of redistributive decisions, one with greater levels of redistribution compared to the expectations of haves, regardless of the process that led to possession. The differences in the binary assessments being made - partial stakeholders forming expectations based on whether or not they have possession; impartial decision makers making choices based on whether or not possession arises through self-determination - may be a source of tension in political decisions. 
Economic success stems from opportunities and personal attributes that are the products of complex interactions between luck and effort (e.g. education opportunities, success in education, personal development, social skills, job acquisition, earning capacity, etc.). Our experiment's results suggest that a binary assessment of selfdetermination plays a simplifying role when impartial redistributors are provided with stakeholder-specific information regarding the different predicaments of haves and havenots. The result points to an insensitivity to marginal changes in information regarding the roles of luck and effort; this implies that more insight into precise mixtures of luck and effort may not shift people's impressions of self-determination.

The political popularity of targeted redistributive programs like earned-income tax credits and welfare work requirements naturally stems from a cognitive process that sorts potential beneficiaries into strict categories of deserving or non-deserving. Such categorization also suggests that redistributive-policy arguments that advance beyond a binary categorization of deserving and non-deserving (Blank, 2003; Bryan, 2005; Howard, 2005; Van Parijs, 1995; Zelleke, 2005) should be expected to be less popular, as they are unlikely to align with people's intuitions about deservingness. 
Table 1: Treatment Procedures

\begin{tabular}{|l|l|l|l|l|l|l|}
\hline Treatment & $\begin{array}{l}\text { Number of } \\
\text { decisions }\end{array}$ & $\begin{array}{l}\text { How senders' } \\
\text { stakes are } \\
\text { determined }\end{array}$ & $\begin{array}{l}\text { How senders' } \\
\text { roles are } \\
\text { determined }\end{array}$ & $\begin{array}{l}\text { Range of } \\
\text { senders' } \\
\text { stakes }\end{array}$ & $\begin{array}{l}\text { How decision } \\
\text { makers' earnings } \\
\text { are determined }\end{array}$ & $\begin{array}{l}\text { Range of } \\
\text { decision } \\
\text { makers' } \\
\text { earnings } \\
\text { through word- } \\
\text { search }\end{array}$ \\
\hline $\begin{array}{l}\text { givenR- } \\
\text { givenI }\end{array}$ & 24 & $\begin{array}{l}\text { Random } \\
\text { amount }\end{array}$ & $\begin{array}{l}\text { Random } \\
\text { assignment }\end{array}$ & $\$ 4-\$ 32$ & Word search & $\$ 4-\$ 36$ \\
\hline $\begin{array}{l}\text { givenR- } \\
\text { earnedI }\end{array}$ & 24 & Word search & $\begin{array}{l}\text { Random } \\
\text { assignment }\end{array}$ & $\$ 6-\$ 38$ & Word search & $\$ 2-\$ 30$ \\
\hline $\begin{array}{l}\text { earnedR- } \\
\text { givenI }\end{array}$ & 24 & $\begin{array}{l}\text { Random } \\
\text { amount }\end{array}$ & $\begin{array}{l}\text { Superior } \\
\text { performance } \\
\text { on a quiz }\end{array}$ & $\$ 4-\$ 34$ & Word search & $\$ 8-\$ 32$ \\
\hline $\begin{array}{l}\text { earnedR- } \\
\text { earnedI }\end{array}$ & 24 & Word search & $\begin{array}{l}\text { Superior } \\
\text { performance } \\
\text { on a quiz }\end{array}$ & $\$ 4434$ & Word search & $\$ 4-\$ 26$ \\
\hline
\end{tabular}

Table 2: Design Matrix

Income

\begin{tabular}{|c|c|c|c|}
\hline & & Earned & Given \\
\hline \multirow{2}{*}{ Roles } & Earned & earnedR-earnedI & earnedR-givenI \\
\hline & Given & earnedR-givenI & givenR-givenI \\
\hline
\end{tabular}


Table 3: Descriptive Statistics

\begin{tabular}{|c|c|c|c|c|c|c|}
\hline & $\begin{array}{c}\text { Observations } \\
\text { (All or a subset } \\
\text { sorted by } \\
\text { Sender stakes } \\
(\mathrm{M}))\end{array}$ & $\mathrm{n}$ & $\begin{array}{l}\text { Mean Percent } \\
\text { Sent to Receiver }\end{array}$ & $\begin{array}{l}\text { Standard } \\
\text { Deviation }\end{array}$ & $\begin{array}{l}\text { Median Percent } \\
\text { Sent to Receiver }\end{array}$ & $\begin{array}{l}\text { Frequency of } \\
\text { Even Splits }\end{array}$ \\
\hline \multirow[t]{4}{*}{ givenR-givenI } & All & 24 & 0.489 & 0.138 & 0.500 & 18 \\
\hline & $\mathrm{M}<10$ & 4 & 0.458 & 0.083 & 0.500 & 3 \\
\hline & $10<\overline{\mathrm{M}} \leq 20$ & 10 & 0.463 & 0.119 & 0.500 & 9 \\
\hline & $M>\overline{20}$ & 10 & 0.528 & 0.171 & 0.500 & 6 \\
\hline \multirow[t]{4}{*}{ earnedR-givenI } & All & 24 & 0.373 & 0.143 & 0.405 & 8 \\
\hline & $\mathrm{M}<10$ & 8 & 0.348 & 0.110 & 0.317 & 2 \\
\hline & $10<\overline{\mathrm{M}} \leq 20$ & 10 & 0.444 & 0.111 & 0.500 & 5 \\
\hline & $M>20$ & 6 & 0.289 & 0.190 & 0.349 & 1 \\
\hline \multirow[t]{4}{*}{ givenR-earnedI } & All & 24 & 0.324 & 0.198 & 0.354 & 6 \\
\hline & $\mathrm{M}<10$ & 4 & 0.313 & 0.239 & 0.375 & 2 \\
\hline & $10<\overline{\mathrm{M}}<20$ & 12 & 0.343 & 0.198 & 0.310 & 3 \\
\hline & $M>\overline{20}$ & 8 & 0.302 & 0.202 & 0.402 & 1 \\
\hline \multirow[t]{4}{*}{ earnedR-earnedI } & All & 24 & 0.336 & 0.125 & 0.345 & 6 \\
\hline & $\mathrm{M} \leq 10$ & 8 & 0.400 & 0.093 & 0.400 & 3 \\
\hline & $10<\overline{\mathrm{M}} \leq 20$ & 10 & 0.303 & 0.131 & 0.292 & 2 \\
\hline & $M>\overline{20}$ & 6 & 0.308 & 0.140 & 0.297 & 1 \\
\hline
\end{tabular}


Figure 1: Distributions of Percentages Redistributed
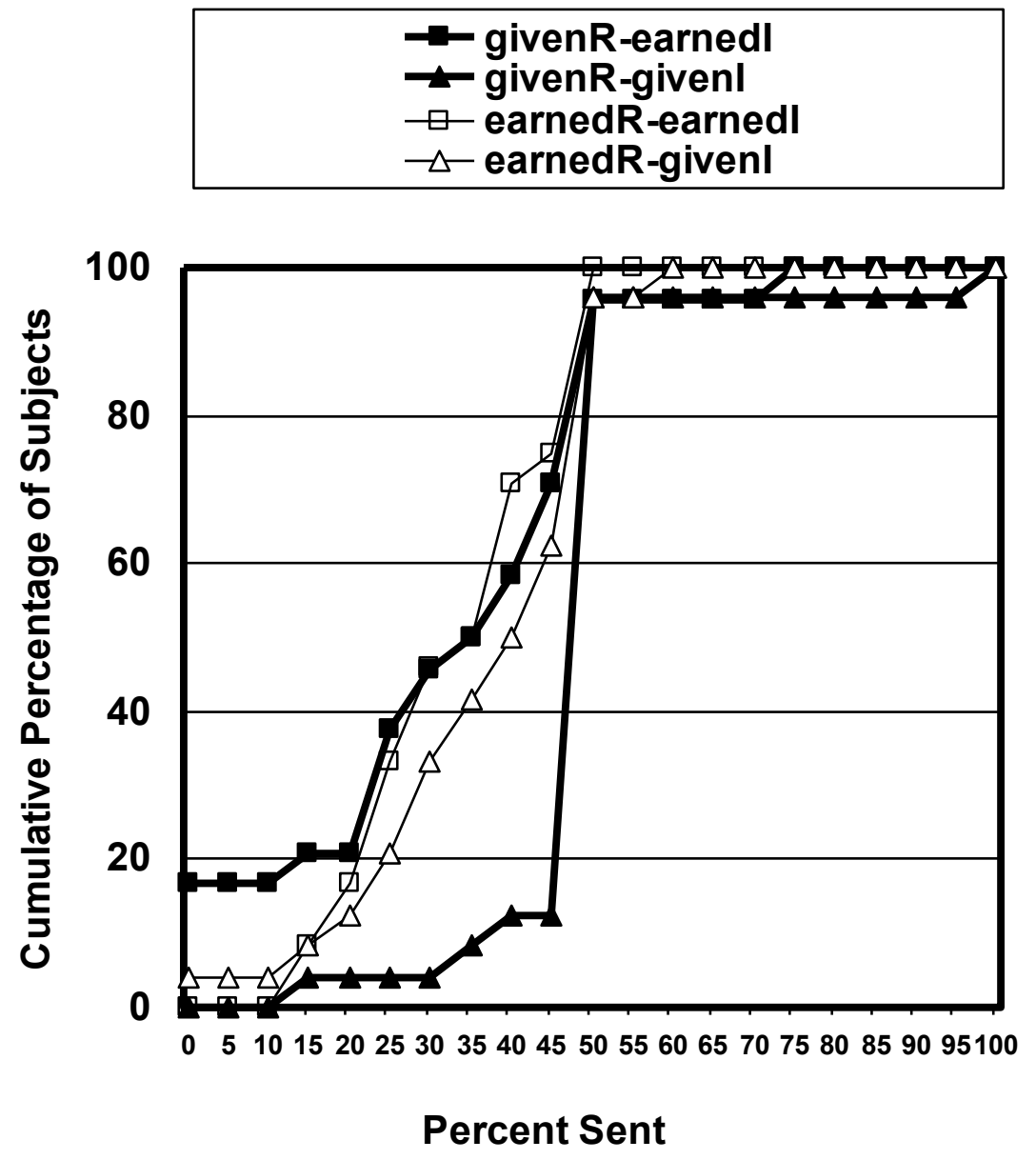
Table 4: Pairwise Wilcoxon Rank-Sum Tests

\begin{tabular}{lccc}
\hline $\begin{array}{l}\text { W Statistic } \\
\text { (Probability significance level) }\end{array}$ & $\begin{array}{c}\text { givenR- } \\
\text { givenI }\end{array}$ & $\begin{array}{c}\text { givenR- } \\
\text { earnedI }\end{array}$ & $\begin{array}{c}\text { earnedR- } \\
\text { earnedI }\end{array}$ \\
\hline \multirow{2}{*}{ earnedR-givenI } & 2.90 & 0.992 & 1.139 \\
& $(0.004)$ & $(0.321)$ & $(0.255)$ \\
givenR-givenI & $*$ & 3.462 & 3.891 \\
& & $(0.0005)$ & $(0.0001)$ \\
givenR-earnedI & $*$ & $*$ & 0.000 \\
& & & $(1.000)$ \\
\hline
\end{tabular}


Table 5: Descriptive Statistics for Expectations

\begin{tabular}{ccc}
\hline Mean $\quad$ Median & $\begin{array}{c}\text { Standard } \\
\text { Deviation }\end{array}$ & $\begin{array}{c}\text { Pairwise Wilcoxon } \\
\text { w/Percentage } \\
\text { Redistributed }\end{array}$ \\
\hline
\end{tabular}

givenR-givenI

Sender Percentage Expected

$(n=22)$

$\begin{array}{lll}0.345 & 0.380 & 0.165\end{array}$

$\mathrm{W}=2.967$

(0.003)

Receiver Percentage Expected

$(\mathrm{n}=19)$

$0.551 \quad 0.500$

0.230

$\mathrm{W}=1.351$

(0.177)

\section{earnedR-givenI}

Sender Percentage Expected

$(\mathrm{n}=18)$

$\begin{array}{lll}0.329 & 0.356 & 0.213\end{array}$

$\mathrm{W}=.519$

(0.604)

Receiver Percentage Expected

$(\mathrm{n}=17)$

$0.527 \quad 0.500$

0.206

$\mathrm{W}=2.374$

(0.018)

\section{givenR-earnedI}

Sender Percentage Expected

$(n=23)$

$0.343 \quad 0.375$

0.195

$\mathrm{W}=0.486$

(0.627)

Receiver Percentage Expected

$(\mathrm{n}=18)$

$\begin{array}{lll}0.484 & 0.500 \quad 0.246\end{array}$

$\mathrm{W}=2.294$

(0.022)

\section{earnedR-earnedI}

Sender Percentage Expected

$(\mathrm{n}=19)$

$0.360 \quad 0.375$

0.154

$\mathrm{W}=0.443$

(0.657)

Receiver Percentage Expected

$(\mathrm{n}=20)$

$0.499 \quad 0.500$

0.206

$\mathrm{W}=3.008$

(0.003) 
Table 6: Pairwise Wilcoxon Comparisons of Senders' and Receivers' Expected Percentages Sent in each Treatment

\begin{tabular}{ll}
\hline & $\begin{array}{l}\text { W Statistic } \\
\text { (Probability } \\
\text { significance level) }\end{array}$ \\
\hline \multirow{2}{*}{ givenR-givenI } & $\begin{array}{l}3.241 \\
(0.001)\end{array}$ \\
givenR-earnedI & $\begin{array}{l}1.905 \\
(0.057)\end{array}$ \\
earnedR-givenI & $\begin{array}{l}2.356 \\
(0.019)\end{array}$ \\
earnedR-earnedI & 2.340 \\
& $(0.019)$ \\
\hline
\end{tabular}

Figure 2: Distributions of Expectations and Percentages Sent

-Decisions

-2 -Sender Expectations $\rightarrow$ Receiver Expectations

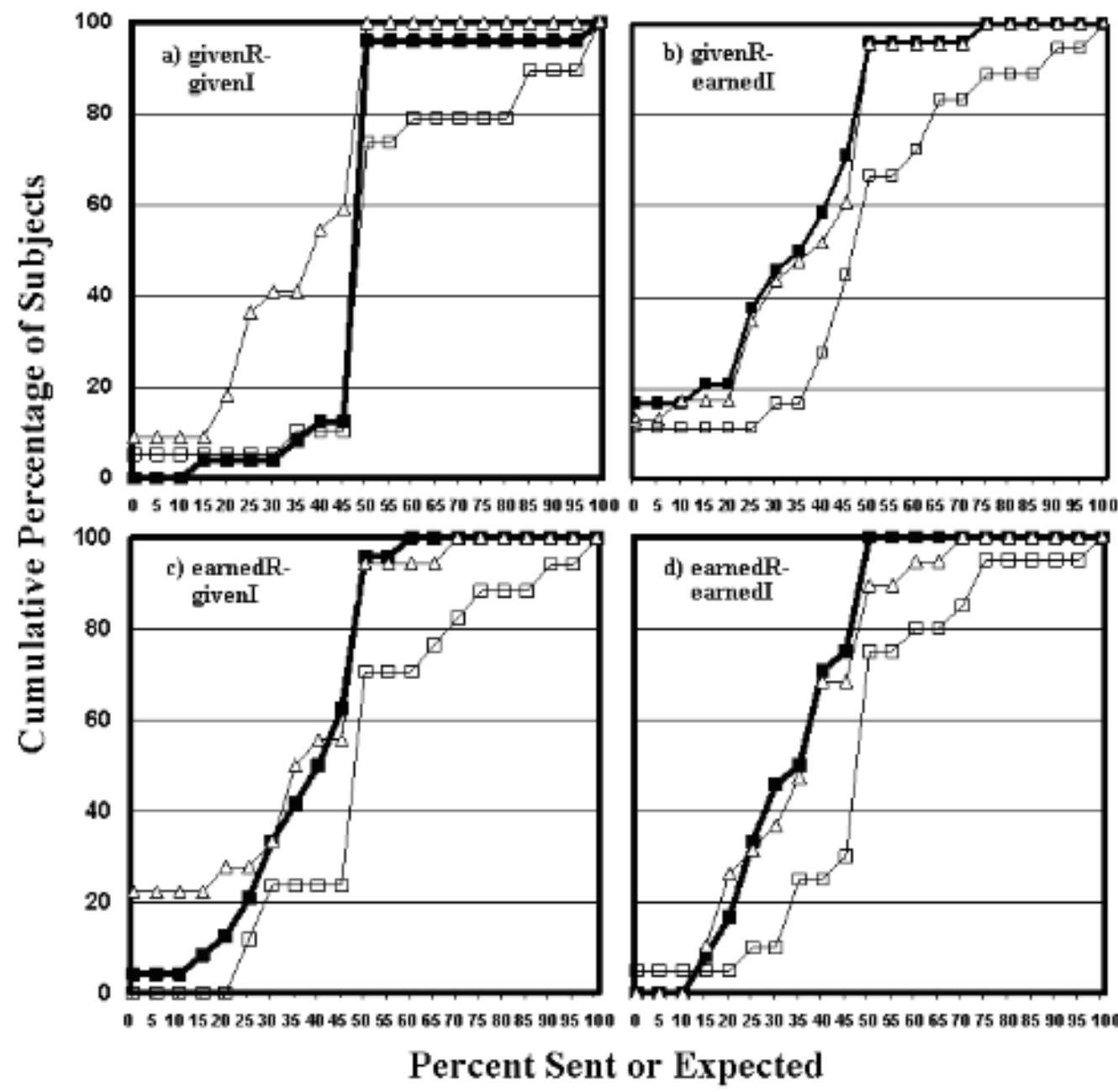




\section{References}

Adams, J. S. (1965). Inequity in Social Exchange. In: Berkowitz, L. (Ed.), Advances in Experimental Social Psychology. New York, Academic Press, 267-299.

Alesina, A., and Angeletos, G. (2005). Fairness and Redistribution. US vs, Europe. The American Economic Review, 95(4), 960-980.

Alesina, A. and Giuliano, P. (2010). Preferences for Redistribution. In: Benhabib, J., Bisin, A. and Jackson M.O. (Eds.) Handbook of Social Economics, Amsterdam, Elsevier, 93-131.

Alesina, A., Glaeser, E., and Sacerdote, B. (2001). Why Doesn't the United States Have a European-Style Welfare State? Brookings Papers on Economic Activity, 2001(2), $187-254$.

Alesina, A. and La Ferrera, E. (2005). Preferences for Redistribution in the Land of Opportunities. Journal of Public Economics, 89 (5-6) 897-931

Benabou, R. (1996). Inequality and Growth. NBER Macroeconomics Annual, (11), 11 92.

Benabou, R. and Ok, E. (2001). Social Mobility and the Demand for Redistribution: the POUM Hypothesis. Quarterly Journal of Economics, 116(2), 447-487.

Bebabou, R. and Tirole, J. (2006). "Belief in a Just World and Redistributive Politics." The Quarterly Journal of Economics, 121(2) 699-746.

Blank, R. (2003). Selecting Among Anti-Poverty Policies: Can an Economist be Both Critical and Caring? Review of Social Economy, 61(4), 447-469.

Boarini, R. and Le Clainche, C. (2009). Social Preferences for Public Intervention: An 
Empirical Investigation Based on French Data. The Journal of Socio-Economics, 38(1) $115-128$.

Burrows, P. and Loomes, G. (1994). The Impact of Fairness on Bargaining Behaviour. Empirical Economics, 19(2), 201-221

Bryan, J. (2005). Have the 1996 Welfare Reforms and Expansion of the Earned Income Tax Credit Eliminated the Need for a Basic Income Guarantee in the US? Review of Social Economy, 63(4), 595-611.

Cappelen, A. W., Hole, A. D., Sørensen, E. Ø. and Tungodden, B. (2007). The Pluralism of Fairness Ideals: An Experimental Approach. The American Economic Review, 97(3), 818-827.

Cappelen, A. W., Konow, J., Sørensen, E. Ø. and Tungodden, B. (2013). Just Luck: An Experimental Study of Risk-Taking and Fairness. The American Economic Review, 103(4), 1398-1413.

Cappelen, A. W., Sørensen, E. Ø. and Tungodden, B. (2010). Responsibility for What? Fairness and Individual Responsibility. European Economic Review, 54(3), 429441.

Cappelen, A. W. and Tungodden, B. (2006). A Liberal Egalitarian Paradox. Economics and Philosophy, 22(3), 393-408.

Cherry, T. L., Frykblom, P. and Shogren, J. F. (2002). Hardnose the Dictator. The American Economic Review, 92(4), 1218-1221.

Corneo, G. and Gruner, H.P. (2002). Individual Preferences for Political Redistribution. Journal of Public Economics, 83(1), 83-107. 
Dickinson, D. L., and Tiefenthaler, J. (2002). What Is Fair? Experimental Evidence. Southern Economic Journal, 69(2), 414-428.

Faravelli, M. (2007). How Context Matters: A Survey Based Experiment on Distributive Justice. Journal of Public Economics, 91(7-8), 1399-1422.

Fong C. (2001). Social Preferences, Self-interest, and the Demand for Redistribution. Journal of Public Economics, 82, 225-246.

Fong, C., Bowles, S. and Gintis, H., 2006. Strong reciprocity and the welfare state. In: Kolm, S.-C., Mercier Ythier, J. (Eds.), Handbook on the Economics of Giving, Altruism, and Reciprocity, vol. 2. North-Holland, Amsterdam.

Fong, C. and Oberholzer-Gee, F. (2011). Truth in giving: Experimental evidence on the welfare effects of informed giving to the poor. Journal of Public Economics, 95(5-6), 436-444.

Galor, O. and Zeira, J. (1993). Income Distribution and Macroeconomics. Review of Economic Studies, 60(1), 35-52.

Gilens, M. (1999). Why Americans Hate Welfare: Race, Media, and the Politics of AntiPoverty Policy. Chicago University Press, Chicago.

Hoffman, E., McCabe, K., Shachat, K., and Smith, V. (1994). Preferences, property rights, and anonymity in bargaining games. Games and Economic Behavior, 7(3), $346-380$.

Hoffman, E., McCabe, K., and Smith, V. (1996). Social Distance and Other-Regarding Behavior in Dictator Games. The American Economic Review, 86(3), 653-660. 
Hoffman, E., and Spitzer, M. L. (1985). Entitlements, Rights, and Fairness: An Experimental Examination of Subjects' Concepts of Distributive Justice. The Journal of Legal Studies, 14(2), 259-297.

Homans, G. (1958). Social Behavior as Exchange. American Journal of Sociology, 63(6), 597-606.

Howard, M. W. (2005). Basic Income, Liberal Neutrality, Socialism, and Work. Review of Social Economy, 63(4), 613-631.

Forsythe, R., Horowitz, J., Savin, N. and Sefton, M.. Fairness in Simple Bargaining Experiments," Games and Economic Behavior, 6(3), 347-69.

Gaeta, J. L. (2011). In the mood for redistribution. An empirical analysis of individual preferences for redistribution in Italy, Unpublished.

Guth, W., Schmittberger, R. and Schwarze, B. (1982). An Experimental Analysis of Ultimatum Bargaining. Journal of Economic Behavior and Organization, 3(4), $367-388$.

Kangas, O. (2003). The Grasshopper and the Ants: Popular Opinions of Just Distribution in Australia and Finland. Journal of Socio-Economics, 31(6), 721-743.

Konow, J. (2009). Is fairness in the eye of the beholder? An Impartial Spectator Analysis of Justice. Social Choice and Welfare, 33(1), 101-127.

Konow, J. (2001). Fair and Square: The Four Sides of Distributive Justice . Journal of Economic Behavior and Organization, 46(2), 137-164.

Konow, J. (1996). A Positive Theory of Economic Fairness. Journal of Economic Behavior and Organization, 31(1), 13-35. 
Konow, J. (2000). Fair Shares: Accountability and Cognitive Dissonance in Allocation Decisions. The American Economic Review, 90(4), 1072-1091.

Larsen, C. A. (2008). The Institutional Logic of Welfare Attitudes: How Welfare Regimes Influence Public Support. Comparative Political Studies, 41(2), 145168.

Luttmer, E. (2001). Group Loyalty and the Taste for Redistribution. Journal of Political Economy, 109 (3), 500-528.

Meltzer, A. and Richard, S. (1981). A Rational Theory of the Size of Government. Journal of Political Economy, 89 (5), 814-927.

Moffitt, R. (1992). Incentive Effects of the U.S. Welfare System: A Review. Journal of Economic Literature, 30(1), 1-61.

Oxoby, R. J. and Spraggon, J. (2008). Mine and Yours: Property Rights in Dictator Games. Journal of Economic Behavior and Organization, 65(3-4), 703-715. Perotti, R. (1993). Political Equilibrium, Income Distribution and Growth. Review of Economic Studies, 60(4), 755-776.

Petersen, M. B., Slothuus, R., Stubager, R. and Togeby, L. (2011). Deservingness versus Values in Public Opinion on Welfare: The Automaticity of the Deservingness Heuristic. European Journal of Political Research, 50(1), 24-52.

Piketty, T. (1995). Social Mobility and Redistributive Politics. Journal of Political Economy, 110 (3), 551-584.

Piven, F. and Cloward, R. (1971). Regulating the Poor. Random House, New York. 
Ruffle B.J. (1998). More Is Better, But Fair Is Fair: Tipping in Dictator and Ultimatum Games. Games and Economic Behavior, 23(2), 247-265.

Schokkaert, E., and Capeau, B. (1991). Interindividual Differences in Opinions about Distributive Justice. Kyklos, 44(3), 325-345.

Schokkaert, E., and Overlaet, B. (1989). Moral Intuitions and Economic Models of Distributive Justice. Social Choice and Welfare, 6(1), 19-31.

Smith, V. L. (1982). Microeconomic Systems as an Experimental Science. The American Economic Review, 72(5), 923-955.

Van Parijs, P. (1995). Real Freedom for All: What (If Anything) Can Justify Capitalism?, Oxford: Oxford University Press.

Zelleke, A. (2005). Basic Income in the United States: Redefining Citizenship in the Liberal State. Review of Social Economy, 63(4), 633-648. 


\section{Appendix A: Main Instructions}

Welcome to today's experiment. Now that we have started it is important that you do not talk or look around at other peoples' desks. Your decisions are private and we respect that privacy. If at any time you have a clarifying question, raise your hand and someone will come over to help you. However, we cannot give advice on what decisions you should make. That's up to you. You're the one making the money.

Read the instructions carefully. At the end of the instructions you will be given a questionnaire to test your understanding of them.

You have drawn an ID letter. For privacy, you will only be known by this ID letter during the experiment.

\section{GIVEN ROLES:}

[In this experiment, there are three roles: Sender, Decision Maker and Receiver. Four of you have been randomly selected to be Senders, four have been randomly selected to be Decision Makers and four have been randomly selected to be Receivers. Each Decision Maker will be randomly matched with a Sender and each Sender will be randomly matched with a Receiver. Senders, Decision Makers and Receivers will not know with whom they are paired. To preserve privacy, Senders, Decision Makers and Receivers will be sitting in different rooms.

If you have drawn the letter A, B, C, or D, you will be a Sender.

If you have drawn the letter E, F, G, or $\mathrm{H}$, you will be a Decision Maker.

If you have drawn the letter I, K, L, or N, you will be a Receiver.]

\section{EARNED ROLES:}

[Four of you have been randomly selected to be Decision Makers. If you drew a D earlier, you will be a Decision Maker.

Two of you have been randomly selected to be Monitors. If you drew an M, you will be a Monitor for today's experiment. The Monitors' role is to ensure that the instructions are followed as stated.

Of the remaining eight individuals, four will be Senders and four will be Receivers. The four who scored highest on the quiz have earned the right to be Senders; the four who scored lowest will be Receivers.] 
Please keep your ticket as you will need to show it to get your payoff.

If you have drawn the letter M, you will be the Monitor for today's experiment. The monitor's role is to insure the instructions are followed as stated.

\section{Sender's Task}

\section{GIVEN ENDOWMENTS:}

[If you are a Sender, you will draw a ticket from a basket. Please make sure that you write your ID letter on the appropriate line. Each ticket will have an amount, in dollars, written on it. You will be given the amount of money that is written on your ticket. After everyone makes their draws, someone will collect the tickets and bring your money back to you in an envelope. The money will be given to you in $\$ 1$ bills. Once you get the envelope and examine its contents, you will then put all of the $\$ 1$ bills in a basket.]

\section{EARNED ENDOWMENTS:}

[If you are a Sender, you will be given a word-search task. Please make sure that you write your ID letter on the appropriate line. You will have 7 minutes to find as many words as you can. You will earn $\$ 2$ for every word that you find. At the end of the 7 minutes, someone will collect the word-search sheets and bring your money back to you in an envelope. The money will be given to you in $\$ 1$ bills. Once you get the envelope and examine its contents, you will then put all of the $\$ 1$ bills in a basket.]

\section{Decision Maker's Decision Task}

If you are a Decision Maker, you will be asked to make only one decision: to choose how many of the $\$ 1$ bills, if any, you want the Sender to send to the Receiver with whom she/he is randomly paired. You will make this decision by filling out a form that will be given to you in an envelope. After you make your decision, you will put the form back in the envelope. Once all decisions are made, the envelopes will be collected.

\section{Decision Maker's Payoff}

If you are a Decision Maker, you will be given a word-search task prior to making your decision. Please make sure that you write your ID letter on the appropriate line. You will have 7 minutes to find as many words as you can. You will earn $\$ 2$ for every word that you find.

Your payoff $=\$ 2 *($ number of words you find $)$

At the end of the 7 minutes, someone will collect the word-search sheets. Your payoff will be paid to you at the conclusion of the experiment; it will not be affected by the decision that you make.

\section{Receiver's Payoff}

If you are a Receiver, you will receive an envelope containing the amount of money that the Decision Maker had the Sender send to you. 
Your payoff $=$ amount sent

For example, if the Decision Maker has the Sender send \$4, then you will receive an envelope containing $\$ 4$.

Your payoff $=\$ 4$

Or if the Decision Maker has the Sender send \$16, then you will receive an envelope containing $\$ 16$.

Your payoff $=\$ 16$

\section{Sender's Payoff}

\section{GIVEN ENDOWMENTS:}

[If you are a Sender, you will be given back the money that is left over after your paired Receiver receives her/his payoff.

Your payoff $=$ amount on the ticket - amount sent

For example, if your ticket says that you are to be given $\$ 20$, and if the Decision Maker has you send \$4, you will have \$16 left over. Your total payoff will equal the \$16 left over.

Your payoff $=\$ 16$

Or, if your ticket says that you are to be given $\$ 20$, and if the Decision Maker has you send \$16, you will have \$4 left over. Your total payoff will equal the \$4 left over.

Your payoff $=\$ 4]$

\section{EARNED ENDOWMENTS:}

[If you are a Sender, you will be given back the money that is left over after your paired Receiver receives her/his payoff.

Your payoff $=\$ 2 *($ number of words you find $)-$ amount sent

For example, if you find 10 words and earn $\$ 2 * 10=\$ 20$, and if the Decision Maker has you send \$4, you will have \$16 left over. Your total payoff will equal the \$16 left over.

Your payoff $=\$ 16$

Or, if you find 10 words and earn $\$ 2 * 10=\$ 20$, and if the Decision Maker has you send $\$ 16$, you will have $\$ 4$ left over. Your total payoff will equal the $\$ 4$ left over. 
Your payoff $=\$ 4]$

Your payoff in this experiment will be completely private. The person who collects the envelopes from the Decision Makers will not see the decisions written on the forms. The envelopes will be given to another experimenter. Using the rules above, this experimenter will put the payoff of each Sender and Receiver into envelopes and return the envelopes to the monitor. The monitor will then ask you for your ID letter. When you present your ticket with your ID letter, you will receive the envelope with your payoff.

This process guarantees that all envelopes will be opened and all money will be handled by someone who sees an ID letter, but not a name, so that nobody is able to match a decision with the identity of either the Senders, Decision Makers or Receivers.

You should not talk to anyone about how much money you, or they, get. Note that these procedures guarantee that no other person will be aware of your payoff.

If you have questions at any time during the experiment, please quietly raise your hand and someone will come over to assist you. Please do not talk with any other participants during the experiment. 
Appendix B: Preliminary instructions in treatments with earned roles

Welcome to today's experiment. Now that we have started it is important that you do not talk or look around at other people's desks. Your decisions are private and we respect that privacy. If at any time you have a clarifying question, raise your hand and someone will come over to help you. However, we cannot give advice on what decisions you should make. That's up to you. You're the one making the money.

You have just drawn a slip of paper. Your slip will either have a Q, a D or an M written on it. There are 8 Q's, 4 D's and 2 M's. For identification purposes, the letters have a subscript number $\left(\mathrm{Q}_{1}, \mathrm{Q}_{2}, \mathrm{D}_{1}, \mathrm{D}_{2}\right.$, etc.). To protect your privacy, you will only be known by ID letters during the experiment.

If you received a $\mathrm{Q}$, you will take a quiz made up of two types of questions. Some questions will ask you about the 2008 U.S. presidential election, while others will ask you about general international affairs. Your performance on the quiz will determine your role in the experiment. Specifically, the four Q's who score highest will earn an opportunity to make money.

If you received a D, you will be a Decision Maker in the experiment. If you received an M, you will be a Monitor in the experiment. The people who received D's or M's will wait silently while others take the quiz. Everyone will receive additional instructions after the quiz.

After these instructions have been read aloud, an experimenter will give the quiz to the 8 people who hold Q's. 
Appendix C: Word-search Task

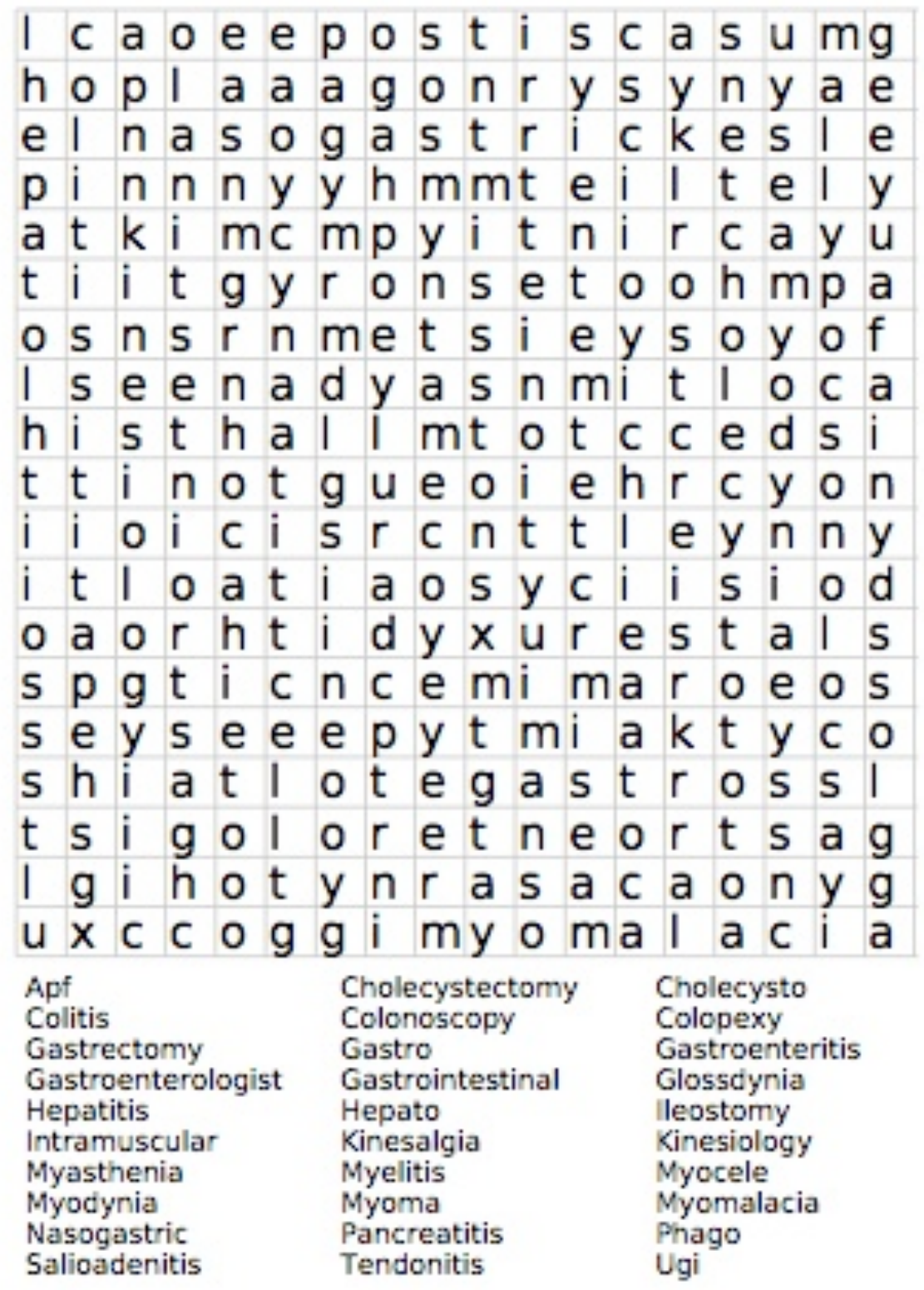




\section{Appendix D: Decision Makers' Questionnaires}

(Note: Senders and Receivers receive a questionnaire that uses different numbers and includes only four hypothetical decisions. Senders' and Receivers' questionnaires also elicit expectations of what the decision makers will do.)

This questionnaire will test your understanding of the instructions that you have read. Feel free to refer back to the instructions as you complete it.

\section{EARNED ROLES-GIVEN ENDOWMENTS:}

[(1) Assume that eight individuals drew tickets with the following numbers written on them:

$\begin{array}{llllllll}3 & 8 & 5 & 7 & 6 & 4 & 2 & 9\end{array}$

Out of these numbers, please circle the four that belong to the Senders. Please underline the four numbers that belong to the Receivers.

(2) In the following scenarios, some decisions of a Decision Maker (DM) are listed. As indicated in the instructions, a Decision Maker is paired with a Sender and a Receiver. You must specify the amount of money that the Receiver, Sender and Decision Maker will receive from each Decision-Maker decision. You will do this by filling in the blank columns labeled "Dollars given to Sender", "Receiver's payoff", "Sender's payoff" and "DM's payoff".

Even though each Decision Maker will make only one decision in the experiment, the questionnaire features multiple hypothetical decisions. This is done so that your understanding can be tested in a more thorough manner. For each decision, please specify the payoff of the Sender, Receiver and Decision Maker. Feel free to refer back to the instructions.

Scenario \#1

\begin{tabular}{|c|c|c|c|c|c|c|}
\hline $\begin{array}{c}\text { Dollar amount on } \\
\text { Sender's ticket }\end{array}$ & $\begin{array}{c}\text { Dollars given } \\
\text { to Sender }\end{array}$ & $\begin{array}{c}\text { DM's } \\
\text { decision }\end{array}$ & $\begin{array}{c}\text { Receiver's } \\
\text { payoff }\end{array}$ & $\begin{array}{c}\text { Sender's } \\
\text { payoff }\end{array}$ & $\begin{array}{c}\text { DM's } \\
\text { performance } \\
\text { on word- } \\
\text { search task }\end{array}$ & $\begin{array}{c}\text { DM's } \\
\text { payoff }\end{array}$ \\
\hline 8 & & 0 & & & 5 words & \\
\hline 10 & & 3 & & & 12 words & \\
\hline 20 & & 7 & & & 6 words & \\
\hline 14 & & 10 & & & 7 words & \\
\hline
\end{tabular}




\section{Scenario \#2}

\begin{tabular}{|c|c|c|c|c|c|c|}
\hline $\begin{array}{c}\text { Dollar amount on } \\
\text { Sender's ticket }\end{array}$ & $\begin{array}{c}\text { Dollars given } \\
\text { to Sender }\end{array}$ & $\begin{array}{c}\text { DM's } \\
\text { decision }\end{array}$ & $\begin{array}{c}\text { Receiver's } \\
\text { payoff }\end{array}$ & $\begin{array}{c}\text { Sender's } \\
\text { payoff }\end{array}$ & $\begin{array}{c}\text { DM's } \\
\text { performance } \\
\text { on word- } \\
\text { search task }\end{array}$ & $\begin{array}{c}\text { DM's } \\
\text { payoff }\end{array}$ \\
\hline 6 & & 5 & & & 5 words & \\
\hline 24 & & 2 & & & 12 words & \\
\hline 16 & & 7 & & & 6 words & \\
\hline 12 & & 12 & & & 7 words & \\
\hline
\end{tabular}

Please quietly raise your hand when this questionnaire is completed.]

\section{GIVEN ROLES-EARNED ENDOWMENTS:}

[This questionnaire will test your understanding of the instructions that you have read. In the following scenarios, some decisions of a Decision Maker (DM) are listed. As indicated in the instructions, a Decision Maker is paired with a Sender and a Receiver. You must specify the amount of money that the Receiver, Sender and Decision Maker will receive from each Decision-Maker decision. You will do this by filling in the blank columns labeled "Dollars earned by Sender", "Receiver's payoff", "Sender's payoff" and "DM's payoff".

Even though each Decision Maker will make only one decision in the experiment, the questionnaire features multiple hypothetical decisions. This is done so that your understanding can be tested in a more thorough manner. For each decision, please specify the payoff of the Sender, Receiver and Decision Maker. Feel free to refer back to the instructions.

Please remember that one will earn $\$ 2$ for each word found in the word-search task.

\section{Scenario \#1}

\begin{tabular}{|c|c|c|c|c|c|c|}
\hline $\begin{array}{c}\text { Sender's } \\
\text { performance } \\
\text { on word-search task }\end{array}$ & $\begin{array}{c}\text { Dollars earned } \\
\text { by Sender }\end{array}$ & $\begin{array}{c}\text { DM's } \\
\text { decision }\end{array}$ & $\begin{array}{c}\text { Receiver's } \\
\text { payoff }\end{array}$ & $\begin{array}{c}\text { Sender's } \\
\text { payoff }\end{array}$ & $\begin{array}{c}\text { DM's } \\
\text { performance } \\
\text { on word- } \\
\text { search task }\end{array}$ & $\begin{array}{c}\text { DM's } \\
\text { payoff }\end{array}$ \\
\hline 4 words & & 0 & & & 5 words & \\
\hline 5 words & & 3 & & & 12 words & \\
\hline 10 words & & 7 & & & 6 words & \\
\hline 7 words & & 10 & & & 7 words & \\
\hline
\end{tabular}




\section{Scenario \#2}

\begin{tabular}{|c|c|c|c|c|c|c|}
\hline $\begin{array}{c}\text { Sender's } \\
\text { performance } \\
\text { on word-search task }\end{array}$ & $\begin{array}{c}\text { Dollars earned } \\
\text { by Sender }\end{array}$ & $\begin{array}{c}\text { DM's } \\
\text { decision }\end{array}$ & $\begin{array}{c}\text { Receiver's } \\
\text { payoff }\end{array}$ & $\begin{array}{c}\text { Sender's } \\
\text { payoff }\end{array}$ & $\begin{array}{c}\text { DM's } \\
\text { performance } \\
\text { on word- } \\
\text { search task }\end{array}$ & $\begin{array}{c}\text { DM's } \\
\text { payoff }\end{array}$ \\
\hline 3 words & & 5 & & & 7 words & \\
\hline 12 words & & 2 & & & 4 words & \\
\hline 8 words & & 7 & & & 10 words & \\
\hline 6 words & & 12 & & & 2 words & \\
\hline
\end{tabular}

Please quietly raise your hand when this questionnaire is completed.] 